\title{
Afterword to Re@ct: Social Change Art Technology
}

\section{SARAH COOK}

Professor, University of Glasgow

\begin{abstract}
This is the afterword to Re@ct: Social Change Art Technology, a special issue of Media- $N$ that gathers contributions from selected participants in the Re@ct symposium held in Dundee, Scotland in 2019. The afterword discusses the artistic origins of common communication technologies, and proposes that artists are well-placed to examine behaviors that may become commonplace as our engagement with technology, and one another, changes as a result of the COVID-19 pandemic.
\end{abstract}

A number of the technologies we now take for granted had their origins in the minds of artists before they became a widely adopted reality. It could be argued that the video conferencing platforms that many of us have found to be a lifeline during the rolling lockdowns resulting from the coronavirus pandemic — such as FaceTime or HouseParty — were born from an idea first realized in the early 1980s by artists engaged in networked performance (Kit Galloway and Sherrie Rabinovitch's Hole in Space was a three-day experiment in connecting unsuspecting passers-by on a street in LA and a street in New York via satellite video phone). ${ }^{1}$ The short messaging systems that have contributed to the spread of misinformation during both the pandemic and the US presidential election campaign owe their origins to a G20 activist gathering (the code and protocols which later became Twitter were written and shared by the Institute for Applied Autonomy, and the artist Rich Pell, to mobilize protestors). ${ }^{2}$ The watch parties, online quizzes, and the "going live" diversions we enjoy were tested in early web-based networked art projects. (The 2002 project $T V$ Swansong by Karen Guthrie and Nina Pope had site-based performances streamed to groups of viewers online ${ }^{3}$; the artists known as Active Ingredient (Matt Watkins and Rachel Jacobs) created the project MakeTV (2004), which allowed everyone with a webcam to have 15 minutes of fame, live; ${ }^{4}$ their follow-up short-lived project Fantasy A-List Generator [2008] was an internet greenroom and interview suite where visitors could don costumes, hats and wigs and be asked banal questions randomly selected from a database with a canned studio audience laughter and applause track, making celebrities of us all.) Even on Zoom, when you turn yourself into a potato, or on Snapchat, when you add silly cartoon glasses to your image, you're engaging in playful behavior that I and many others first experienced in an interactive art work (Tine Papendick's Digital Puppetry installation at Eyebeam in 2008). ${ }^{5}$ 
These histories are not widely known, or well documented, and of course all tech developments can be said to have any number of origins and engineering antecedents. But the behaviors these technologies engender in their users are rarely cited as having precedents in other disciplines, when in fact they might. The collection of texts in this issue of Media- $N$ addresses the past, present, and future of art and activism through the lens of digital technology. By bringing into view the strategies that artists use to connect people across distances and across difficult political and social issues, we are reminded that changes in our engagement with technology are in fact changes in our engagement with one another.

The essays in this collection consider technologies such as newspapers, video cameras, voting machines, drones, machine learning systems, augmented reality apps, and video games (among others), but do so through the eyes of artist-activists, offering new understandings of the empowering roles those technologies have in our lives. Without getting too philosophical about it, the distinction German philosopher Martin Heidegger made about equipment ${ }^{6}$ (and French philosopher Gilbert Simondon made about assemblages ${ }^{7}$ ) matters here- that technological tools cannot be understood separately from the politics of their use, that they are "ready-to-hand" as part of a network of other tools and organizations, a means to an end, consciously used as part of a bigger endeavor. The essays in this issue remind us that when we engage with digital affordances in order to connect more easily with one another, we might be taking on changes to our "norms" and our lived experiences, and that we may not know yet the longer-term effects of this empowerment. It is for this reason that we do well to continue to look at how artists use technology, and the changes they manifest in societies when they share those efforts with others.

In the half year since the Re@ct symposium and throughout this globally unsettling period, following the work of activist artists has continued to provide encouraging evidence that it is possible to change society, to influence behaviors, to introduce a mindfulness to our reliance on seemingly dumb but scarily smart tools. Artist Kyle MacDonald released the code for a webbrowser plug-in that would remove any news about COVID-19 from your browsing experience ${ }^{8}$; Danielle Baskin and Max Hawkins released QuarantineChat to connect random users via phone to help reduce social isolation'; Martine Stig released WeAlgo, a playful experiment intended to become a filter for video conferencing software that turns the facial recognition algorithm around to show you the points it sees and allow you to customize your "mask."10 These are just three of the dozens of recently launched socially engaged digital projects which meet you on screen, where you are spending most of your time, encountering news about the world, and connecting with one another. They are projects that address the trade-off between personal privacy and public life. More than ever, as our behaviors in the digital world and the real world continue to reinforce one another - with both positive and negative consequences - we need artists to teach us how to creatively use technologies. When the protests in Minneapolis about the death of George Floyd were at their height, collectively edited online spreadsheets helped neighbors protect one another against the violent attacks of white supremacist groups aiming to increase discord. When visits to care homes were curtailed, video conferencing apps enabled relatives to hear each other more clearly through the window separating the inside from the outside world. Our private and public spaces, the world on screen and the world beyond the window, are inextricably linked by and through digital technology, and activist artists can show us how to break those boundaries and rebuild or reroute the connections between us. 


\section{ENDNOTES}

1. For more about Hole in Space, see http://www.ecafe.com/getty/HIS/

2. For more about TXTMob, see https://en.wikipedia.org/wiki/TXTMob,

http://techpresident.com/news/22775/txtmob-twitter-how-activist-tool-took-over-conventions

and https://www.wired.com/2004/08/text-messages-for-critical-masses/

3. For more about TVSwansong, see https://www.swansong.tv/

4. For more about Make TV, see https://www.matt-watkins.net/work/maketv/, and for Fantasy AList Generator, see https://www.matt-watkins.net/work/fantasy-a-list-generator/

5. For more about Digital Puppetry, see http://ti-pi.de/work/digital-puppetry/

6. Heidegger, Martin, and William Lovitt. The Question Concerning Technology, and Other

Essays. (New York: Harper \& Row, 1977).

7. Simondon, Gilbert. On the Mode of Existence of Technological Objects (Minneapolis:

University of Minnesota Press, 2017).

8. For more about COVIDPause see https://github.com/kylemcdonald/COVIDPause

9. For more about Quarantine Chat, see https://quarantinechat.com/

10. For more about WeAlgo, see https://wealgo.org/

\section{REFERENCES}

Heidegger, Martin, and William Lovitt. The Question Concerning Technology, and Other Essays. (New York: Harper \& Row, 1977).

Simondon, Gilbert. On the Mode of Existence of Technological Objects. (Minneapolis: University of Minnesota Press, 2017).

Sifry, Micah, L. "From TXTMob to Twitter: How an Activist Tool Took Over the Conventions," in Techpresident.com, August 25, 2012. Online. Available at:

http://techpresident.com/news/22775/txtmob-twitter-how-activist-tool-took-over-conventions

Terdiman, Daniel. “Text Messages for Critical Masses." Wired Magazine, August 12, 2004.

Available at: https://www.wired.com/2004/08/text-messages-for-critical-masses/

\section{AUTHOR BIO}

Sarah Cook is a curator, writer and researcher based in Scotland. She is Professor of Museum Studies in Information Studies at the University of Glasgow. Until 2019 she was a curator for Scotland's only digital arts festival NEoN Digital Arts and was founder/curator of LifeSpace Science Art Research Gallery in the School of Life Sciences, University of Dundee (20132018). Sarah has curated and co-curated international exhibitions worldwide for twenty years including: Sleep Mode (2020) and 24/7: A Wake-up Call For Our Non-stop World (2019) both at Somerset House in London; The Gig Is Up (2016) at V2_Institute for Unstable Media in Rotterdam; New Media Scotland Alt-w (2014) at the Royal Scottish Academy, SSA Annual Exhibition in Edinburgh; Not even the sky: Thomson \& Craighead (2013) at MEWO Kunsthalle in Memmingen; Biomediations (2013) at Transitio_MX_05, the festival of electronic arts and 
video in Mexico City; Broadcast Yourself (2008) for AV Festival 08 in Newcastle; Database Imaginary (2004) and The Art Formerly Known As New Media (2005) both for the Walter Phillips Gallery, in Banff, Canada. In 2008-2009 Sarah was the inaugural curatorial fellow at Eyebeam Art and Technology Center in New York, and she worked as adjunct curator of new media at BALTIC Centre for Contemporary Art until 2006. From 1999 to 2005 Sarah worked as a guest curator and researcher in residence at the Banff Centre, for the International Curatorial Institute and what was the Banff New Media Institute. Publications include Euphoria \& Dystopia: The Banff New Media Institute Dialogues (Banff Centre Press, 2011, co-edited with Sara Diamond); INFORMATION (Documents of Contemporary Art, Whitechapel and MIT Press, 2016); and Rethinking Curating: Art After New Media (MIT Press, 2010; Chinese edition 2016, co-authored with Beryl Graham). She holds a Master's degree from CCS at Bard, and a PhD from the University of Sunderland (2004) 